\title{
The Value of a "Coyne": The Diefenbaker 120| Government and the 1961 Coyne Affair.
}

Daniel Macfarlane, University of Ottawa

This study explores the political aspects of the 1961 Coyne Affair, which saw the Governor of the Bank of Canada, James Coyne, promote restrictionist economic policies that were at odds with the expansionist monetary approach of the Diefenbaker government. The situation was complicated by unclear governmental responsibilities regarding the Bank and a contentious pension issue, leading to the Progressive Conservative cabinet's request for the governor's resignation, a demand he refused. The Affair became a public controversy involving opposition parties and the Canadian media, and personal animosities clouded the judgment of both the Tory government, led by Prime Minister John Diefenbaker and Minister of Finance Donald Fleming, and Coyne. However, the Progressive Conservative's attempt to force Coyne's resignation was ultimately justified due to his contrary economic policies and the extent to which he overstepped his position as governor and engaged in political machinations. The Coyne Affair led to the restructuring of the relationship between the Bank and the federal government and contributed to the fall of the Diefenbaker government, Senate reform, and economic nationalism.

The Diefenbaker era in Canadian politics is perhaps best remembered for issues such as the Avro Arrow, "One Canada", and the prime minister's relationship with American President John F. Kennedy. The legacy and repercussions of the Progressive Conservatives' six years in power have been extensively studied,

Past Imperfect

14 [2008] | () |ISSN 1711-053X | eISSN 1718-4487 
but an event with which many contemporaries of the period were familiar has since received little scholarly attention. The Coyne Affair, as several weeks in June and July of 1961 have become colloquially known, centered on James Coyne, the Governor of the Bank of Canada, his falling out with the Diefenbaker government over economic policies, and the subsequent debacle over his requested resignation.

Prior to 1961, the Diefenbaker cabinet had been at odds with Coyne over Canadian monetary policy - and his Liberal Party connections certainly did him no favours in the eyes of the prime minister - but the Progressive Conservatives were nonetheless prepared to wait out Coyne's term as governor, which was due to conclude at the end of 1961. However, the situation was exacerbated by the circumstances under which Coyne was granted a considerable pension increase and Coyne's public attacks on the Diefenbaker cabinet. These tensions erupted into a controversy that saw harsh words exchanged in the House of Commons and the Canadian media but, behind the rhetoric and accusations, involved significant questions about Canadian monetary policy and the relationship between the Governor of the Bank of Canada and the federal government.

This study will focus on the political and personal aspects of the Coyne incident. It will be argued here that both the Tory government and Coyne were guilty of allowing personal feelings to cloud their judgment, at times taking on the appearance of a duel between Minister of Finance Donald Fleming and the Governor of the Bank of Canada. The situation was further aggravated by ambiguous lines of responsibility between the cabinet and Bank of Canada for monetary policy. Nevertheless, the Progressive Conservative cabinet's request for Coyne's 
resignation was ultimately justified due to the fact that his economic policies conflicted with those put forward by the elected representatives of the people, and the extent to which he overstepped his position as governor and engaged in political machinations. The Coyne Affair would have significant ramifications for the individuals involved, the Diefenbaker 122 government, the Bank of Canada, and Canadian monetary policy. Moreover, the Coyne Affair can also be linked to Senate reform, notions of responsible government, and the growth of economic nationalism.

James Coyne was appointed to a seven-year term as Governor of the Bank of Canada on January 1, 1956 by Louis St. Laurent's Liberal administration. Although there was some initial surprise that Coyne had been selected instead of Louis Rasminsky, Coyne would not become well known to the public at large until he was thrust onto the national scene in 1961. The Diefenbaker government came to power in 1957 and returned the next year with the largest electoral victory up to that point in Canadian history.

According to the 1935 Bank of Canada Act, the Directors of the Bank and the government were given the power to appoint the governor, but the act did not give them the requisite power to remove the governor from his position. Only an act of Parliament could do so. The Bank of Canada was prescribed full authority over monetary policy and its own interest rates without input from the government or the minister of finance. The government was to be responsible for fiscal policy and debt management, in which it could act on the advice and with the assistance of the Bank of Canada. In practice, the Bank was solely responsible for monetary supply while the government was 
discharged of any culpability, which was the position of the Diefenbaker government and their immediate predecessors. Walter Harris, who was the previous Liberal finance minister, had suggested that the governor of the Bank was in fact completely independent as far as monetary policy was concerned and not subject to the will of the government. This resulted in the socalled "Harris Doctrine," which held that there were two sovereignties in Canadian economics - the government (specifically the minister of finance) and the Bank of Canada each with its own authority and responsibilities.

Relations with the chartered banks were also a prominent facet of the Bank's role, although this relationship was already strained by 1957. Moreover, there were complaints that Coyne was uncooperative and that his "tight money" policies were strangling commercial credit. Relatively minor complaints of this nature, as well as others concerning the deterioration of the Canadian economic situation, continued over the following years. It became apparent that Coyne's restrictionist views were at odds with the expansionary policies advocated by the Diefenbaker administration (with the prime minister himself leading the way), along with the question of whether monetary policy should be directed primarily to fighting unemployment rather than inflation. By the fall of 1960, cabinet members Alvin Hamilton and George Hees, among others, were urging Fleming "to remove the restraining hand of Coyne from the economy." Additionaly, Diefenbaker apparently became convinced that Coyne was one of his enemies within established Ottawa circles who were determined to sabotage the Tories.

Historical literature on the Diefenbaker era tends to ignore the Coyne Affair - it has also been labeled the Coyne Crisis 
- with J.L. Granatstein's Canada 1957-1967: The Years of Uncertainty and Innovation, which was published in 1986, and Bruce Muirhead's 1999 Against the Odds: The Public Life and Times of Louis Rasminsky, serving as the primary exceptions. Several studies contemporary to the Coyne Affair, such as the Canadian Annual Review and Patrick Nicholson's Vision and 124| Indecision, do sketch some of the details. Donald Fleming's memoirs provide the most in-depth and personal account of the Coyne situation, whereas John Diefenbaker's One Canada is at its most revealing in what is omitted. Unfortunately, Coyne himself has not provided any memoirs or a detailed account of what transpired. The Diefenbaker papers from the Diefenbaker Canada Centre Archives in Saskatoon provide possibly the best evidence from Coyne's point of view, in the form of his correspondence with Fleming. The minutes of the Senate's Banking and Commerce Committee hearings also give some insight into Coyne's thinking. The Diefenbaker papers allow a partial reconstruction of the debates that were taking place in cabinet. Peter Stursberg provides a useful compilation of recollections by various participants in the event, and Lester Pearson's memoirs add some additional information.

Denis Smith's excellent Rogue Tory: The Life and Legend of John G. Diefenbaker, has relatively little on the Coyne Affair. Smith does relate that Fleming originally supported the restrictionist policies advocated by Coyne and the Bank of Canada, but had switched sides by 1961 in favour of Diefenbaker's expansionist instincts. Fleming mentions in his memoirs that he had at one time been inclined toward restrictionist policies, but he does not specifically state that he was opposed to them prior to 1961 either. The available evidence supports Smith's contention

$$
\begin{gathered}
\text { Past Imperfect } \\
14 \text { [2008] | (C) |ISSN 1711-053X | eISSN 1718-4487 }
\end{gathered}
$$


to at least some extent. Merrill Menzies, a noted economic advisor to Diefenbaker, recalls that Fleming originally favoured restrictionist policies but reluctantly acquiesced to Diefenbaker's preferences after the 1959 budget when the prime minister forced his views upon the minister of finance. Nevertheless, there is no doubt that by 1961 Fleming was at least officially opposed to the policies Coyne promulgated.

Coyne's policies were thoroughly discredited by economic experts around the country for being restrictionist, antiinflationary, and protectionist. For example, on December 8, 1960, Fleming had received a number of letters signed by seventeen economists who called for Coyne's resignation. The Liberal opposition had themselves been denouncing these types of policies since the late $1950 \mathrm{~s}$, and by 1961 there seems to have been little, if any, support for Coyne's position. During the height of the Coyne Affair, the Liberals would be forced to admit that they were opposed to the governor's economic opinions and recommendations. Thus, it seems a safe generalization to say, based on the virtually unanimous opinion of economic experts, that Coyne's policies were strongly admonished.

The nascent tension between Coyne and cabinet was exacerbated by the governor's penchant for making public speeches, the first dating to 1959 , in which he blamed Canadian economic woes on fiscal policies. These were clearly the responsibility of the government, with the result that Coyne's public statements were seen as attacks on the Diefenbaker government, although Coyne disavowed any intentions of that sort. In place of the cabinet's fiscal policies, Coyne called for changes that seemed protectionist and authoritarian in nature. His clear intent was to exercise greater control over the Canadian 
economy and to reduce the inflow of foreign capital.

By 1960, Coyne's speeches were causing the government embarrassment because his statements were interpreted abroad as "statements of Canadian government policy" and "were frightening off American and foreign investors." Furthermore, they caused concern among senior cabinet ministers because they 126 contradicted the government's stance on the economic situation. In the House of Commons, the Liberals pounced on the dispute and sought to gain political currency by claiming the government was responsible for monetary policy. This kind of attack would continue over the following months.

By February of 1961, cabinet unanimously disapproved of re-appointing Coyne when his term ran out at the end of the year. However, they decided not to inform him or the public that such a position had taken, as it "might provoke a furor." Cabinet had no authority to unilaterally dispose of Coyne, and a request for his resignation might "precipitate a battle royal." At this juncture, they seemed to believe that their best option would be to wait out Coyne's term. Fleming met with Coyne after the latter indicated that the minister of finance was supposedly unwilling to do so. Coyne maintained that he was trying to save the country from economic ruin and did not intend to undermine the government. The governor further defended himself by contending that the misunderstanding stemmed from his failure at "getting his ideas through" to Fleming, but the meeting ended without any reconciliation of views.

Several days later, on March 21, came a discovery that would transform the entire quarrel. Fleming learned that Coyne would receive a pension of $\$ 25,000$ a year upon the completion of his term on December 31, 1961, which was a substantial

$$
\begin{gathered}
\text { Past Imperfect } \\
14 \text { [2008] | (C) |ISSN 1711-053X | eISSN 1718-4487 }
\end{gathered}
$$


increase - almost double - over the previous allotment of $\$ 13,000$. Over the next week, cabinet became aware of the circumstances in which the pension had been granted: a by-law had been passed by the Bank of Canada's Board of Directors back on February 15 of the previous year. Before 1954, all Bank of Canada by-laws adopted by the Board of Directors had been submitted to cabinet, but in that year the Department of Justice ruled that cabinet approval was unnecessary. From that point on, by-laws were not submitted to the Governor-in-Council (with one exception in 1957). However, the Bank of Canada Act prescribed that all by-laws must be published in the Canada Gazette. This had not been the case with the February 15, 1960 by-law establishing Coyne's pension.

Fleming describes his own reaction as having been "appalled" at the news, while cabinet was collectively "shocked" and the prime minister "enraged." They cited the examples of Graham Towers, who had been the Governor of the Bank of Canada for twenty years and yet was entitled to a pension of only $\$ 13,750$, and former Prime Minister Louis St. Laurent, who received substantially less. The minister of finance himself felt that the publication in the Gazette was not a "condition precedent to validity of the pension by-law," but was bewildered that such an occurrence could have come about without his knowledge. Deputy Minister of Finance Ken Taylor was ex-officio a non-voting member of the Board of Directors, but had been unable to attend the Board's February 15 meeting. Taylor sent Wynne Plumptre as his replacement; however, Plumptre failed to inform Fleming of what transpired, although Fleming did not hold him responsible because Plumptre was neither adequately instructed on the pension by-law nor aware of its implications. 
It must be pointed out that Coyne did not propose or even vote for the by-law himself. Diefenbaker would later claim that there was impropriety on Coyne's part since the governor possessed a veto over the pension decision, but this was a stretch, since it had been proposed by a subcommittee of three directors and then approved unanimously. Cabinet realized " $[\mathrm{t}]$ here was no 128 real ground for an attack on the integrity of the governor, who had not inspired the by-law amendments that had improved his pension position" and they "should not make him a martyr." They resolved to make it clear that they desired Coyne's resignation "because of his repeated public attacks on the government's fiscal policy, because he had embroiled the Bank in public controversy and because the morale of the Bank had been seriously impaired by his actions." Over the following weeks, cabinet would continue to debate the validity of, and possible methods for reversing, the pension arrangement, and despite their professions to make apparent their desire to remove Coyne because of his fiscal policies, the Progressive Conservatives would skew the situation to give the appearance that Coyne had clandestinely given himself the pension.

Cabinet unanimously decided that Coyne must be relieved of his duties at once since the governor's acceptance of the pension without disclosure to the government was considered reprehensible. Essentially, the pension increase was just the final straw in a long line of problems with Coyne. However, Fleming convinced his colleagues that the Board had the authority to give the pension increase and that an attack on the by-law via Coyne's dismissal would jeopardize the pensions of all employees of the Bank.

The probes into the circumstances surrounding the Past Imperfect 14 [2008] | (C) |ISSN 1711-053X | elSSN 1718-4487 
pension, along with preparing the budget and considerations over possible amendments to the Bank of Canada Act, and differences of opinion in the cabinet, resulted in Fleming waiting over two months to directly confront Coyne about the pension matter. On May 30, the two met and Fleming informed Coyne that cabinet was asking for his resignation prior to the Bank's Board of Directors meeting on June 12. Interestingly, Coyne would write several days later that the reasons given to him for the request were that it "would be to have me holding office as Governor for the next seven months knowing I was not to be re-appointed, and that early arrangements should be made for my successor to take over." This had been the procedure in previous Canadian and British cases where the governor was aware ahead of time that he would not be returning for another term. Conversely, Fleming reports that he gave a variety of reasons, the main one being that the government was planning to initiate policies with which Coyne was sure to disagree.

Coyne quickly set out to construct "as strong a defensive position as possible," according to Fleming. The Bank governor sent the minister of finance a memorandum stating that the Bank must always cooperate with the government's decisions; Fleming concluded that Coyne was seeking to make peace or build up a case on self-serving evidence indicating that he wished to cooperate with the government. On June 12, Coyne called for an informal meeting with the Directors but failed to appear, allegedly because he had learned that they intended to call for his resignation. The Board meeting resumed the next morning, and Coyne asked to be excused before the Board moved to request that he step down. He returned to the meeting shortly after noon. In the meantime, he had released a press statement where he gave 
the impression that only the government, and not the Board, was calling for his dismissal.

Shortly after Coyne returned from making the statement, the Board passed a resolution, 9 to 1, calling for Coyne's resignation. Coyne did not resign but, instead, called a press conference and distributed copies of four letters he had sent to 130 Fleming on June 9. In the following days, Coyne would repeatedly release copies of correspondence between Fleming and himself, later resulting in accusations of breach of the oath of secrecy he had taken upon assuming his position. He sent a letter to Fleming the next day, contending that he would not resign because there was no "valid case" for him to do so, and that the Board had only asked for his resignation because the government had requested that it do so and that he had been "surprised and disturbed" by the request. Indeed, it seems that the Board was calling for the resignation based almost solely on the government's adamant request, and Coyne refused to step down "merely because the government of the day asks him to," although he would claim that, if had not been for the government's invocation of the pension issue for his dismissal, he would have complied.

Cabinet met the following day, and Fleming announced they would take legislative action to remove Coyne, as Parliament was the only body with power to do so. In Fleming's words, "Coyne had declared war on the government," and his actions were "part of a clearly calculated attempt to build up controversy." The opposition parties in the House immediately sought to further exploit the situation and bring down heavy criticism on the Conservatives, and repeated their call for a House of Commons committee to investigate the matter.

On June 20, the same day Fleming was to reveal the new 
budget, cabinet initiated legislation that would become known as Bill C-114. The timing of the Bill was at least partially intended prevent Coyne from interfering with the government's new budget, which was slated to be released that same day. The Bill contained a single clause: "The office of the Governor of the Bank of Canada shall be deemed to have become vacant immediately upon the coming into force of this act." Discussions were heated in the House of Commons after it was given First Reading, as the opposition Liberals accused the Progressive Conservatives of undermining the Bill of Rights, responsible government, and failing to be accountable for the Bank of Canada's policies, accusations the Liberals had been making in the preceding months.

The Liberals admitted that if the Governor of the Bank of Canada could not cooperate with the government, then he would have no alternative but to resign. On June 26, Lester Pearson, the Liberal Leader of the Opposition, himself conceded that "the governor's usefulness has ended" and that Coyne's policies were inappropriate when taking into account the current economic situation in Canada. According to the Grits, the issue had become one of responsible government. In the Canadian parliamentary tradition, a concomitant aspect of responsible government has been ministerial responsibility, whereby ministers are responsible for the policies and actions of public officials in their department. The minister of finance was therefore theoretically accountable for the Governor of the Bank of Canada, and the discord between Fleming and Coyne was thus seized upon by the opposition as an abdication of responsible government, even if, conventions surrounding the link between ministerial responsibility and responsible government had been somewhat tenuous and in flux

\footnotetext{
Past Imperfect
14 [2008) | (C) |ISSN 1711-053X| elSSN 1718-4487
} 
for decades.

The Liberals further claimed that the situation had created a major constitutional crisis, and accused the Tories of using Coyne as a scapegoat for their own failing policies. The opposition had been arguing for months that the minister of finance did need to take responsibility for the Bank of Canada's

132 monetary policies. The government's resignation request created a whole new set of questions, such as how Fleming could claim that his policies had been at odds with Coyne's for several years after claiming the opposite in previous statements in the House. Furthermore, how could cabinet request Coyne's resignation if they were not responsible for his actions?

Pearson lamented that with Bill C-114, the political executive was seeking to make rubber stamps of the elected representatives of the people because they were being asked to take action without information and "to give a blank cheque to the government to control the bank without any parliamentary scrutiny." If cooperation between the governor and cabinet was not maintained, and the governor did not resign voluntarily, a responsible government should bring the situation to the attention of Parliament so that they could conduct an inquiry in accordance with "simple decency and justice." In failing to do so by way of parliamentary committee, the opposition contended, the supremacy of Parliament was being undermined.

Cabinet debated the question of a parliamentary committee on June 30 and decided that Coyne should not be entitled to such a hearing; according to Fleming, it would just be providing him with "a forum to propagate his groundless political attacks against the government and play his publicity game." Furthermore, why should Coyne be accorded equal status with the 
government by being given such a forum? Cabinet was of the opinion that such a concession would set a precedent that would undermine responsible government - every time a public servant has a grievance he would be entitled to appear before a parliamentary committee. Diefenbaker further believed that setting up a committee would "open up a can of worms" where the Grits would use the opportunity for political ends by debating relations between the government and the Bank of Canada as well as the question of responsibility for monetary policy.

While there was a certain logic to the cabinet's decision, this view arguably contradicted the Bill of Rights - the principles of innocence until proven guilty, the right to a fair trial, and the right to defend one's self - which had been enacted by the very same administration the previous year, as Pearson had pointed out in the House on several occasions. Furthermore, it is quite debatable that a dangerous precedent would have been set if Coyne were not allowed to testify in front of a committee. Coyne represented much more than a simple public servant; at stake were issues of governmental responsibility and jurisdiction, issues that deserved open examination. It seems improbable that Parliament would, even in theory, henceforth grant a hearing to every public official who had a dispute with a minister of the government.

Cabinet was probably correct in assuming that Coyne would use such a forum to his advantage and continue many of his accusations, based on his behavior over previous weeks and months and the fact that he had already taken ample opportunity to air his views in public. However, cabinet was essentially seeking to protect itself from criticism, which they felt justified in doing considering the nature of the aforementioned criticism, as they worried that giving Coyne an open and official forum would only

Past Imperfect

14 [2008] | (C) |ISSN 1711-053X | elSSN 1718-4487 
result in further defamation. Of course, the legitimacy of this decision is still open to interpretation. If nothing else, the refusal was construed by the opposition and the media as an abdication of the tenets of responsible government.

Debate resumed in the House of Commons on July 4, and the Bill was given second reading by a vote of 153 to 42 . Over the 134 following days, Bill C-114 moved through the Committee of the Whole and then Third Reading without amendment, due to the Progressive Conservative majority, but the matter was far from over. The Bill went to the Senate and was quickly given second reading and referred to the Senate's Banking and Commerce Committee. In committee, it soon became apparent that the Bill was being ambushed, for the Liberals held a sizable majority in the appointed upper house. Coyne was invited before the committee; Fleming was not, although Diefenbaker and cabinet had already decided he would not attend in any case. The Liberals, who were using the committee to attack the Conservatives, excluded evidence from anyone but Coyne. This effectively undermined the Liberal contention that the purpose was for a "fair trial" but Coyne's hearing is useful in that it provides a fuller version of his side of events, even though Fleming accuses him of manhandling the record and mangling the facts.

Coyne told the Committee that he had acted based on what he felt were important principles: the best interests of Canada, the integrity of the Bank of Canada, the office of the governor, and his own person. The Conservatives had charged Coyne with violating the oath of secrecy taken by public servants since he had released to the public correspondence between Fleming and himself; Coyne rebutted that he "had a right and duty for the benefit of Parliament and the people of Canada" to make

Past Imperfect

14 [2008] | (C) |ISSN 1711-053X| eISSN 1718-4487 
the information public once attacks were made on him personally and on the integrity of his office. Coyne further decried the "sorry tactics" of the government and what he considered their "abuse of power" while stating that he disregarded the Board of Directors' call for his resignation because their "political loyalties" had been invoked. Furthermore, there could be no conflict over monetary policy since he contended that the government had no policy and refused responsibility for any.

After several days of deliberations, the Banking and Commerce Committee reported to the Senate its recommendation that the Bill should not be further debated and that Coyne had not acted inappropriately while in office. They decided that Coyne was not in violation of holding his office on "good behavior", but the unofficial reason for the recommendation seemed to hinge on Coyne's statement that he intended to resign. As one of the Senators stated:

I would be quite prepared on the assertion of his [Coyne] alone to vote against proceeding with this bill. The thing the government wished to achieve is the departure of Mr. Coyne from the position of the Governor of the Bank of Canada. Well, if that is achieved, why do we need to go and further soil the pages of our history with a transaction of this kind, and I think it is in the public interest in every respect that that be avoided.

Coyne did indeed resign that same day. He released a statement in which he declared that he regarded the verdict by the Committee and the full Senate as "a vindication of my own conduct, of my personal honour and of the integrity of the position of the

$$
\begin{gathered}
\text { Past Imperfect } \\
14 \text { [2008]| (C) |ISSN 1711-053X| |eISSN 1718-4487 }
\end{gathered}
$$


Governor of the Bank of Canada as established by Act of Parliament."

Diefenbaker's memoirs contain only a few lines on the Coyne episode and cast the prime minister in a generally infallible light. However, Fleming does criticize him with respect to several aspects of the Coyne Affair. First, Diefenbaker claims in his 136 memoirs that he suggested granting the request for a parliamentary committee, which Fleming maintains was never the case. Secondly, Fleming contends that Diefenbaker was as responsible as anyone for the outcome, for he "presided day after day at the Cabinet meetings where all decisions were taken."

Coyne, as well as several newspaper commentaries, paint a different picture. The Governor of the Bank of Canada accused Diefenbaker of being "the evil genius behind the whole matter. It was his unbridled malice and vindictiveness which seized on the Bank of Canada's pension fund provisions." The question of the role Diefenbaker played in attempting to dispose of Coyne may never be known for certain, although he appears to have played an influential role. The popular reaction was much clearer: a reported 60 percent of the 76 percent of the people who had heard about the controversy sided with Coyne, while only 9 percent came out in favour of the Tories. The fact that the matter was played out in public seemingly increased the stakes, perhaps explaining to some extent why the matter became so personal at times.

In retrospect, it appear Coyne was motivated by the desire to defend his personal integrity and honestly believed his actions were justified because he was fighting for important principles, although he also stated during the Senate Banking and Commerce Committee hearing that he regretted some of the things he had 
said and done after May 30. Jack Pickersgill, a frontbencher and one of the "Four Horseman" skilled at attacking the Tory government, was quite vocal in the House of Commons during the crises. But even he, one of Coyne's closest personal political friends, did not approve of Coyne's speech-making campaign. Fleming also expressed some regret over the whole incident, and his memoirs lack the bitterness one might expect. Fleming himself contends that he never took the matter personally which, if true, lends credence to the argument that the minister of finance acquiesced in large part to Diefenbaker and the cabinet.

The individual disputes were eventually superseded by the issue of whether the government had responsibility for the actions taken by the Bank. According to the Tories they did not but, realistically, at least some responsibility was necessary. It appears the Progressive Conservatives did use Coyne to an extent as a scapegoat, partly explaining their absolution of any responsibility. The pension fund was seized upon to provide an excuse for Coyne's removal, as there were five main reasons for the governor's falling out with the Conservative administration: (1) in his speeches he had shown that he openly differed with government on important policies; (2) he had embroiled the Bank of Canada in political controversy; (3) his views were incompatible with far-reaching programs upon which the government was about to embark; (4) he did not possess the confidence of the Canadian financial institutions; (5) his pension arrangements.

The decision not to allow a parliamentary committee was seemingly based on the desire to avoid again debating the issues of responsibility and the relationship between the government and the Bank of Canada, and to avoid further negative media coverage 
of the government's handling of the issue. Technically, as the Senate Committee found, Coyne's tenure constituted "good behavior" in office and cabinet could not force him to resign on "pleasure". At the same time, given the situation, the Progressive Conservative position is quite understandable. A case could certainly be made that Coyne had repeatedly violated "good 138| behavior". Questions regarding which side was more in the wrong may never be completely reconciled, as there are obviously strongly competing versions of what transpired.

Nevertheless, Diefenbaker was in the right to seek Coyne's resignation in a general sense, since the governor had advocated economic policies that clashed with those of the government and had gone out of his way to try and stir up public support against the government. Focusing on the pension issue appears somewhat petty in retrospect, but given the surreptitious manner in which the pension was granted, and the fact that a problematic individual was being granted a pension substantially larger than those received by other outstanding public servants, the decision to ask for Coyne's removal at that point is understandable. Once Coyne had been called to resign, he attempted to politically influence the debate and publicly attack the government despite his non-political role, while the Liberals played the political opportunists and cynically exploited the issue for all that it was worth. In the process, the Coyne problem assumed larger and larger proportions, becoming a full-blown controversy in which no side was completely free of culpability.

The repercussions of the Coyne Affair are perhaps less problematic to evaluate. Nothing tangible was immediately achieved, except for Coyne's resignation, and there were some positive effects. The ambiguous relationship between the 
government and the Bank of Canada would be clarified in the following years - according to Pierre L. Siklos, "the Coyne Affair focused policy makers' minds on clarifying the limits of the responsibility of the governor in dictating the adoption of a particular monetary policy strategy." Louis Rasminsky, who succeeded Coyne, enjoyed amicable and productive relations with the government. 1967 would finally see the amending of the Bank of Canada Act and the definition of spheres of responsibility governing cooperation between the Bank and the government.

There were several far-reaching results that are not as immediately obvious. The Senate reform that took place in 1965 and put the compulsory retirement age at 75 for Senators derived largely from an earlier attempt in 1962 by Diefenbaker to do the same. While Diefenbaker's legislation, introduced in April shortly before Parliament was dissolved for an election, was probably more symbolic than a serious attempt to pass the bill, this seminal attempt was spurred on by the Senate's handling of two pieces of government legislation in July of 1961. These were Bill C-72, a bill designed to amend the standing customs-tariff legislation, and Bill C-114, the attempt to get rid of Coyne. It therefore logically follows that if the Coyne Affair had a direct impact on the first attempt at Senate reform, then the actual reform several years later - which adopted essentially the same provisions as had been proposed in 1962 - also had roots in the Coyne Affair.

The Coyne Affair has also been linked to the growth of economic nationalism, which is most commonly associated with Walter Gordon. Stephen Azzi writes that, after Gordon, Coyne was the most influential Canadian to express concern over foreign ownership in the 1960s. Although Gordon disagreed with most of Coyne's economic policies, they shared the belief that foreign 
investment needed to be curtailed. Coyne worried that foreign control of Canadian industry would lead to the loss of Canadian political independence.

It would seem that the Coyne Affair hurt the Diefenbaker government at the polls. They dropped from 208 to 116 seats in the 1962 election. While it is difficult to determine the extent to 140 which this was an electoral response to what transpired with Coyne, it no doubt played a role in the electorates' disaffection with the Progressive Conservatives, and Coyne's statements about Diefenbaker contributed to the popular image of the former prime minister as exceedingly vindictive and paranoid. Pearson, whose Liberals replaced the Progressive Conservatives with a minority government in the 1963 election, contends that the Tories had shown a "singular ineptitude in dealing with [Coyne]." He argues that the Affair gave the Liberal opposition more confidence and that they became more vigorous during 1961 in their attacks on the government. Pearson also contends that the Diefenbaker government's reputation was severely damaged, resulting in disenchantment within both the caucus and the electorate at large. Alvin Hamilton, a member of the Diefenbaker cabinet, went even further: "I don't think there is any question that [the Coyne Affair] was the destruction of the Diefenbaker government right then and there." Coyne's reputation appears to have remained intact if the popular opinion polls serve as evidence. Moveover, he was named the "Canadian Newsmaker of the Year" for 1961 by the Canadian Press. After his resignation, however, Coyne quickly faded from the media spotlight and maintained a low public profile. 


\section{Works Cited}

\section{Primary Sources}

Canada, House of Commons, Debates, 1960-1961, v. I-VII. Canadian Annual Review. Toronto: York University of Toronto Press, 1961.

Diefenbaker Canada Centre Archives: Volume 56, Personal and Confidential Series, Files 118.1-118.4

Diefenbaker, John G. One Canada. Memoirs of the Right Honourable John G.

Diefenbaker. Volume Two: The Years Of Achievement, 1957-1962. Toronto: The MacMillan Company of Canada, 1976.

Fleming, Donald. So Very Near: The Political Memoirs of the Honourable Donald Fleming. Volume Two: The Summit Years. Toronto: McClelland and Stewart, 1985.

Library and Archives Canada. RG 2, Volume 6177, Cabinet Conclusions. Senate of Canada. Proceedings of the Standing Committee on Banking and Commerce, 1960-1961, v.2, 4th Session, 24th Parliament.

\section{Secondary Sources}

Albinski, Henry S. "The Canadian Senate: Politics and the Constitution", in American Political Science Review, volume 57, 1963.

Azzi, Stephen. Walter Gordon and the Rise of Canadian Nationalism. Montreal: McGill-Queen's University Press, 1999.

Krehm, William. A Power Unto Itself: The Bank of Canada. Toronto: Stoddart Publishing, 1993.

Laidler, David E.W. How Shall We Govern the Governor?: A Critique of the Governance of the Bank of Canada. Toronto: C.D. Howe Institute, 1991.

Munro, John A. and Alex I. Inglis, eds. Mike: The Memoirs of the Right Honourable Lester B. Pearson. Volume 3: 1957-1968. Toronto: University of Toronto Press, 1975.

Muirhead, Bruce. Against the Odds: The Public Life and Times of Louis Rasminsky, Toronto: University of Toronto Press, 1999.

Nicholson, Patrick. Vision and Indecision. Don Mills, ON: Longmans, 1968. 
Siklos, Pierre L. "Revisiting the Coyne Affair: A Singular Event That Changed the Course of Monetary Policy" (Wilfrid Laurier University, Department of Economics Working Papers Series, 2007).

Smith, Denis. Rogue Tory: The Life and Legend of John G. Diefenbaker. Toronto: Macfarlane, Walter, and Ross Inc., 1995.

Stursberg, Peter. Diefenbaker: Leadership Gained, 1956-62. Toronto: University of Toronto Press, 1975.

142

Past Imperfect 